\title{
STUDY OF OXIDATION PROCESSES IN DUCK MEAT WITH APPLICATION OF ROSEMARY AND GRAPE SEED EXTRACTS
}

\author{
Nataliia Bozhko \\ Department of technology of milk and meat \\ Sumy National Agricultural University \\ 160 G. Kondratieva str., Sumy, Ukraine, 40021 \\ natalybozhko@ukr.net \\ Vasyl Tischenko \\ Department of technology of milk and meat \\ Sumy National Agricultural University \\ 160 G. Kondratieva str., Sumy, Ukraine, 40021 \\ tischenko_1958@ukr.net \\ Vasil Pasichnyi \\ Department of technology of meat and meat products \\ National University of Food Technologies \\ 160 G. Kondratieva str., Sumy, Ukraine, 40021 \\ Pasww1@ukr.net \\ Andriy Marynin \\ Laboratory of problem research \\ National University of Food Technologies \\ 68 Volodumurska str., Kyiv, Ukraine, 01601 \\ a_marinin@ukr.net \\ Maksym Polumbryk \\ Department of Livelihoods security \\ National University of Food Technologies \\ 68 Volodumurska str., Kyiv, Ukraine, 01601 \\ mx_pol@yahoo.com
}

\begin{abstract}
The substantiation of the expedience of using antioxidants of a natural origin to decelerate oxidation processes in different meat products is an urgent direction of these studies. The prospective way of a solution of the problem of meat products oxidation spoilage is the use of vegetable extracts. The experimental studies of the effective use of the composition of rosemary and grape seed extracts in Peking duck forcemeat at the long storage were realized. Their influence on the dynamics of hydrolytic and peroxide oxidation of forcemeat lipids was studied. The analysis of oxidation secondary products accumulation was realized at the same time.

The positive effect of the combined use of rosemary and grape seeds extracts on frozen Peking duck forcemeat was established, the optimal concentration of offered preparations was determined.

Keywords: composition of extracts, hydrolytic oxidation of lipids, peroxide oxidation of lipids, thiobarbituric number.

\section{Introduction}

At storage of meat products, especially ones with an increased fat content, oxidation processes that lead to the decrease of energetic and biological value of products may take place [1]. For preventing oxidative spoilage, anti-oxidizing additives of a natural or artificial origin are used in the meat products technology [2-7]. Artificial antioxidants, despite their high effectiveness, have a risk for human health. That is why scientists realize searching studies of new, save and natural sources of antioxidants, no less effective than artificial ones [8-11].
\end{abstract}


Today the effectiveness of different types of anti-oxidizing preparations of a natural origin, caused by the high content of flavonoids and other biologically active compounds, is proved [12-19]. Vegetable antioxidants have the essential potential for the use in the meat products technology, but their introduction has certain limitations because of absence of data about the effectiveness in different types of meat raw material [20-25]. So, the study of the effectiveness, dosage features, synergetic properties of preparations of natural antioxidants is an urgent problem of today.

The main aim of this research was the study of oxidation processes in Peking duck forcemeat at using a rosemary extract (RE) and grape seed extract (GSE) and determination of optimal parameters of antioxidants use.

\section{Materials and Methods}

For studying the set task, Peking duck meat (SSTC 3143:200) was used as a model to study $\mathrm{RE}$ and GSE influence on the course of oxidation processes in meat products. Poultry meat (carcass) (general technical conditions) differs by the high content of lipids - 37-40\%, including PUFA $-17,5 \%$. Duck forcemeat was prepared according to the standard technological scheme. Duck meat was crumbled, cleaned of tendons and comminuted on the gyroscope with the grating orifices diameter 2-3 mm. A rosemary extract (Food Ingredients Mega Trade, USA) was introduced to it (Fig. 1). A grape seed extract was added to forcemeat as a second antioxidant preparation. It was received by the water-alcohol extraction (1:4) of grape seeds powder of red grape "Isabella" - "Mak-Var", Ukraine by 60 \% solution of ethyl alcohol (Fig. 2).

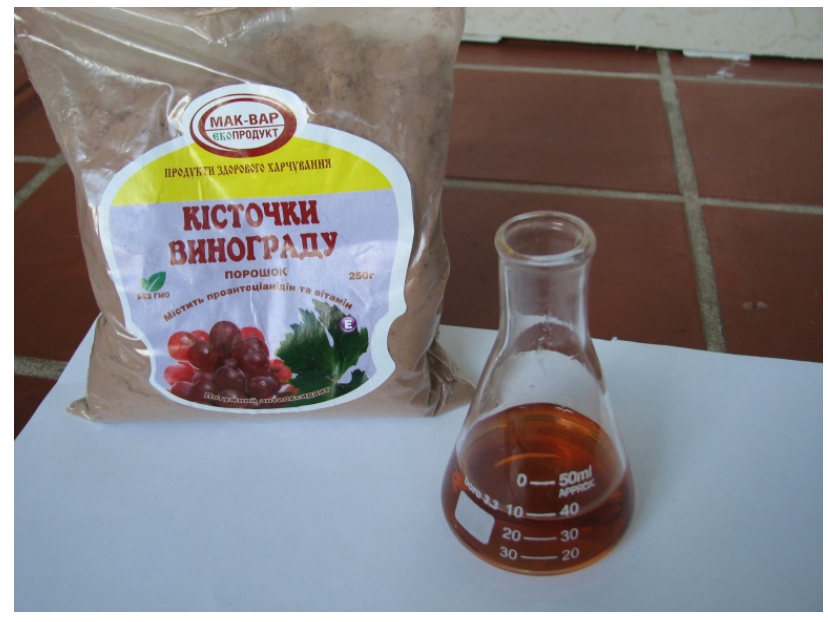

Fig. 1. Extract of grape seed powder

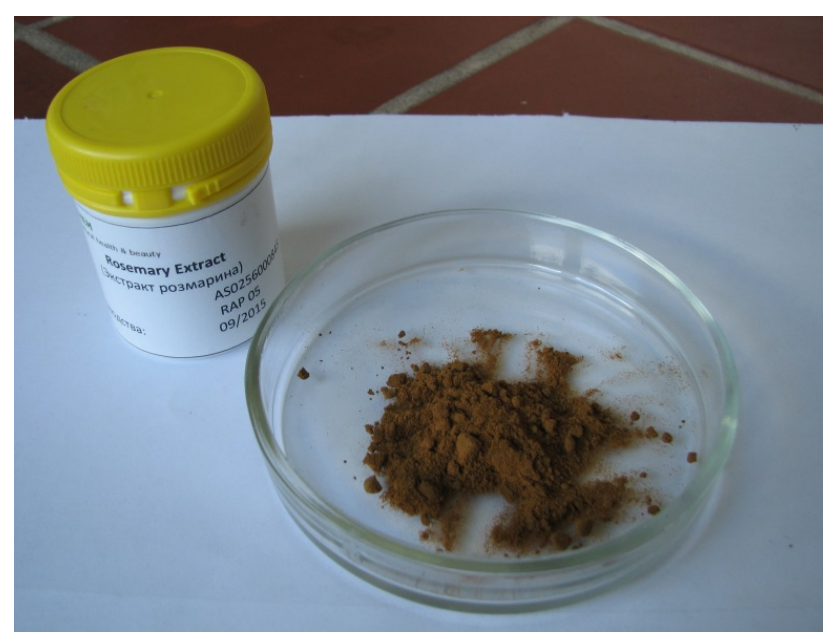

Fig. 2. Rosemary extract 
Studied samples of forcemeat were added with aforesaid preparations by the following scheme:

No. 1 - RE $0,02 \%+$ GSE $0,1 \%(0,12 \%)$;

No. 2 - RE $0,04 \%+$ GSE $0,2 \%(0,24 \%)$;

No. 3 - RE $0,06 \%+$ GSE $0,3 \%(0,36 \%)$

to the raw material mass, the forcemeat sample without antioxidants was a control. The recommended concentration of antioxidants for using in meat products technology varies from 0,01 to $0,1 \%$. [7, 9, 12, 24, 25, 28, 29] So, correspondent extracts combinations were selected taking into account the content of different groups of substances with an antioxidant property and synergetic effect of their combined use. Model samples were stored at the temperature $-10{ }^{\circ} \mathrm{C}$ (temperature of storage of frozen cut semi-products) during 90 days. Control parameters were acid and peroxide numbers (AN and PN), thiobarbituric number (TBN). The study of these parameters was realized according to generally accepted methods [26].

An acid number was determined by titration of a batch by sodium hydroxide in the concentration with fenolftalein alcohol solution [26]. 3-5 g of studied forcemeat was weighted in the conic retort with the volume $150-200 \mathrm{~cm}^{3}$ with the error no more than $0,001 \mathrm{~g}$. The batch was heated on the water bath, added with $50 \mathrm{~cm}^{3}$ of neutralized ether-alcohol mixture and shaken. Then 3-5 drops of fenolftalein alcohol solution with the mass share $1 \%$ were added. The received solution at permanent shaking was titrated fast by the solution of potassium hydroxide with the molar concentration $0,1 \mathrm{~mol} / \mathrm{dm}^{3}$ to the distinct rose coloration that doesn't disappear during $1 \mathrm{~min}$. The acid number was calculated by the formula:

$$
\mathrm{X}=(\mathrm{V} \times \mathrm{K} \times 5,61) / \mathrm{m}
$$

where $\mathrm{V}$ - volume of potassium hydroxide solution, with the molar concentration $0,1 \mathrm{~mol} / \mathrm{dm}^{3}$, spent for titration; $\mathrm{K}$ - correction to alkali solution for recalculation on the distinct $\left(0,1 \mathrm{~mol} / \mathrm{dm}^{3}\right)$ one; 5,61 - number of milligrams of potassium hydroxide, contained in $1 \mathrm{~cm}^{3}\left(0,1 \mathrm{~mol} / \mathrm{dm}^{3}\right)$ of solution; $\mathrm{m}$ - forcemeat batch mass, $\mathrm{g}$.

The method of PN determination is based on the batch extraction by the mixture of chloroform and icy acetic acid and further titration by the sodium hyposulfite solution with the previously added starch solution [26]0,8-1 g of a batch, weighted with exactness no more than $0,0002 \mathrm{~g}$ were placed in the conic retort with the stopper, melt on the water bath and added with $10 \mathrm{~cm}^{3}$ of chloroform and $10 \mathrm{~cm}^{3}$ icy acetic acid on the retort wall. $0,5 \mathrm{~cm}^{3}$ of saturated, freshly prepared potassium iodine solution is added fast. The retort was closed with the stopper, the content was mixed by turning movements and put to a dark place for 3 minutes. After keeping $100 \mathrm{~cm}^{3}$ of distilled water with preliminary added $1 \mathrm{~cm}^{3}$ of starch solution with the mass share $1 \%$ was added in the retort. Then it was titrated by the sodium hyposulfite solution with the molar concentration $0,01 \mathrm{~mol} / \mathrm{dm}^{3}$ to elimination of blue coloration.

To verify the clearness of reagents, the control determination without a batch was realized. The peroxide number was calculated by the formula:

$$
\mathrm{X}=\left[\left(\mathrm{V}-\mathrm{V}_{1}\right) \times \mathrm{K} \times 0,00127 \times 100 / \mathrm{m}\right.
$$

where $\mathrm{V}$ - volume of sodium hyposulfite solution with the molar concentration $0,01 \mathrm{~mol} / \mathrm{dm}^{3}$, spent for titration at the main experiment with a forcemeat batch, $\mathrm{cm}^{3} ; \mathrm{V}_{1}$ - volume of the sodium hyposulfite solution $\left(0,01 \mathrm{~mol} / \mathrm{dm}^{3}\right)$, spent for titration at the control experiment without a forcemeat batch, $\mathrm{cm}^{3} ; \mathrm{K}$ - coefficient of correction to sodium hyposulfite for recalculation on the distinct $\left(0,01 \mathrm{~mol} / \mathrm{dm}^{3}\right)$ solution; 0,00127 - number of grams of iodine, equivalent to $1 \mathrm{~cm}^{3}$ $\left(0,01 \mathrm{~mol} / \mathrm{dm}^{3}\right)$ of sodium hyposulfite; $\mathrm{m}$ - mass of a batch of studied forcemeat, $\mathrm{g}$.

TBN was determined by measuring the intensity of coloration of the mixture of distillate of the studied sample with the thiobarbituric acid solution (1:1) after keeping on the water bath for 35 minutes on the spectrophotocolorimeter "Spекоl-11" (Germany) (Fig. 3) at the wave length $535 \mathrm{~nm}$ [27]. 


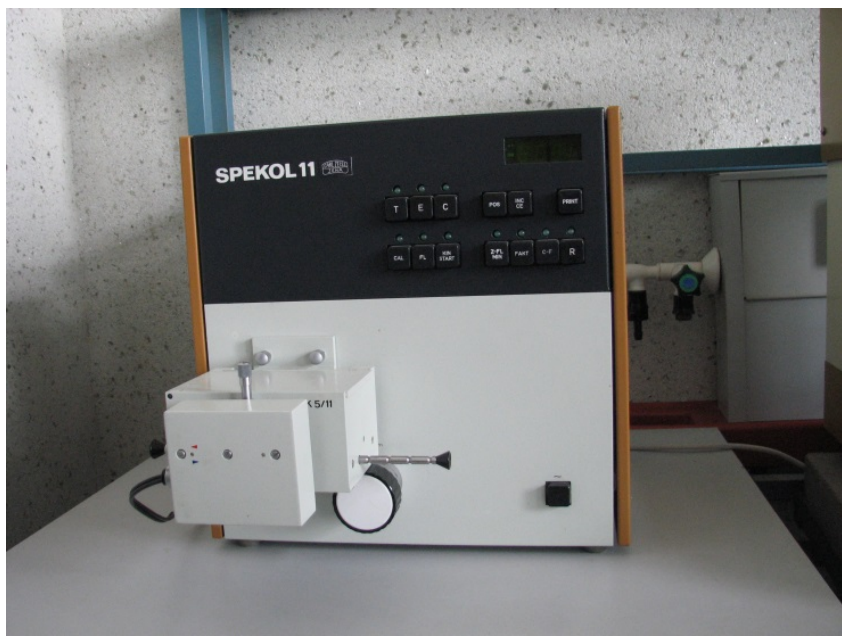

Fig. 3. Spectrophotocolorimeter "Spekol-11" (Germany)

50 of forcemeat batch were put to the porcelain mortar, $50 \mathrm{~cm}^{3}$ of distilled water were measured by the glass cylinder, added to the mortar and ground by the pestle to the homonymous state. The prepared retort was quantitatively transferred to the Kjeldahl retort, remains were washed from the mortar by $47,5 \mathrm{~cm}^{3}$ of distilled water and $2,5 \mathrm{~cm}^{3}$ of hydrochloric acid were added. The distillation in Kjeldahl apparatus (Fig. 4) was realized, by collecting $50 \mathrm{~cm}^{3}$ of distillate in the volumetric flask. $5 \mathrm{~cm}^{3}$ of distillate were taken, inset in the retort with the stopper, $5 \mathrm{~cm}^{3}$ of thiobaturic acid were added, the stopper was closed, and the retort was put on the boiling water bath for $35 \mathrm{~min}$, time was noted by the stopwatch.

At the same time the control experience was realized, using $5 \mathrm{~cm}^{3}$ of distilled water instead of a distillate. Then the solutions were cooled in flowing cold water during $10 \mathrm{~min}$, time was noted by the stopwatch, and the optic density at the wave length $(535 \pm 10) \mathrm{nm}$ as to the control solution was measured.

The thiobarbituric number, mg of MA (malonic alehyde)/kg of a product, was calculated by the formula:

$$
\mathrm{X}=\mathrm{D} \times 7,8,
$$

where D - optic density of the solution; 7, 8 - coefficient of proportional dependency of MA density on its concentration in the solution. This coefficient is a permanent value.

The absolute error of measurements was determined using Student criterion, the reliable interval $\mathrm{P}=0,95$, number of repeats in calculations $3-4$, number of parallel tests of studies samples -3 .

\section{Results}

The results of the study of the acid number dynamics in Peking duck forcemeat with extracts of rosemary and grape seed demonstrated the high effectiveness of preparations. The process of free fatty acids accumulation in forcemeat was decelerated in direct proportion to studied preparation dosage. The use of the composition in the combination No. 3 allowed to decrease the acid number at the end of storage by $32,5 \%$.

The introduction of rosemary and grape seed extracts compositions favored the deceleration of the process of primary oxidation products accumulation. At the end of storage PN reached its highest value in the control sample, whereas in experimental ones with antioxidant preparations this index was by $55,67 \%$ less.

As a result of the deceleration of forcemeat lipids peroxide oxidation, the positive influence of the introduced composition on the accumulation of secondary oxidation products such as pentanal, hexanal, malonic aldehyde and other was noted. It was proved by the received results. At the 
end of storage TBN of studied samples varied at the level 2,81 4,27 mg of MA/kg of a product that is by $32,2255,39 \%$ lower comparing with the control.

\section{Conclusions}

The studies demonstrated that the combined use of rosemary and grape seed extracts effectively decelerates the process of oxidation of meat lipids with the high fat content, namely duck meat. Due to synergetic effect, the offered combination of extracts stabilized processes of hydrolytic and peroxide oxidation of lipids that favored the increase of the quality and safety of a ready product. This fact is also testified by the deceleration of the accumulation of secondary products of forcemeat lipid fraction oxidation.

The realized studies allowed to determine the most optimal dosage of the selected composition, namely, rosemary extract $-0,06 \%$ and grape seed extract $-0,3 \%$.

The received results may be introduced in the technology of cut semi-products, especially meat-containing ones, which fat content is not standardized and a risk of products spoilage as a result of oxidation processes exists.

The authors plan to use the presented method of lipids stabilization at manufacturing meat-containing semi-products of duck meat and other types of a fat-containing raw material.

\section{References}

[1] Maqsood, S., Benjakul, S. (2011). Comparative studies on molecular changes and pro-oxidative activity of haemoglobin from different fish species as influenced by pH. Food Chemistry, 124 (3), 875-883. doi: 10.1016/j.foodchem.2010.07.011

[2] Shahidi, F. (Ed.) (1997). Natural Antioxidants. Chemistry, Health Effects and Applications. Champaign: AOCS Press, 432.

[3] Pasichnyi, V. M., Marynin, A. I., Moroz, O. O., Heredchuk, A. M. (2015). Development of combined protein-fat emulsions for sausage and semifinished products with poultry meat. Eastern-European Journal of Enterprise Technologies, 1 (6 (73)), 32-38. doi: 10.15587/1729-4061.2015.36232

[4] Masuda, T., Inaba, Y., Takeda, Y. (2001). Antioxidant Mechanism of Carnosic Acid: Structural Identification of Two Oxidation Products. Journal of Agricultural and Food Chemistry, 49 (11), 5560-5565. doi: $10.1021 /$ jf010693i

[5] Saito, S., Okamoto, Y., Kawabata, J. (2004). Effects of Alcoholic Solvents on Antiradical Abilities of Protocatechuic Acid and Its Alkyl Esters. Bioscience, Biotechnology, and Biochemistry, 68 (6), 1221-1227. doi: 10.1271/bbb.68.1221

[6] Johnston, J. E., Sepe, H. A., Miano, C. L., Brannan, R. G., Alderton, A. L. (2005). Honey inhibits lipid oxidation in ready-to-eat ground beef patties. Meat Science, 70 (4), 627-631. doi: 10.1016/j.meatsci.2005.02.011

[7] Kumar, Y., Yadav, D. N., Ahmad, T., Narsaiah, K. (2015). Recent Trends in the Use of Natural Antioxidants for Meat and Meat Products. Comprehensive Reviews in Food Science and Food Safety, 14 (6), 796-812. doi: 10.1111/1541-4337.12156

[8] Ukrainets, A., Pasichniy, V., Zheludenko, Yu., Zadkova, S. (2016). Oleoresins effect on cooked poultry sausages microbiological stability. Ukrainian Food Journal, 5 (1), 124-134.

[9] McBride, N. T. M., Hogan, S. A., Kerry, J. P. (2007). Comparative addition of rosemary extract and additives on sensory and antioxidant properties of retail packaged beef. International Journal of Food Science \& Technology, 42 (10), 1201-1207. doi: 10.1111/j.1365-2621.2006.01342.x

[10] Velasco, V., Williams, P. (2011). Improving meat quality through natural antioxidants. Chilean Journal of Agricultural Research, 71 (2), 313-322. doi: 10.4067/s0718-58392011000200017

[11] Ukrainets, A., Pasichniy, V., Zheludenko, Yu. (2016). Antioxidant plant extracts in the meat processing industry. Biotechnologia Acta, 9 (2), 19-27. doi: 10.15407/biotech9.02.019

[12] Brewer, S. (2008). Preserving beef quality with natural antioxidants. Research knowledge management, 1-14.

[13] Tolkunova, N., Bydiuk, A. (2002). Vliyanye rastytelnikh ekstraktov na okyslytelnie protsessi v pashtete. Myasnaya industriya, 7, 26-27. 
[14] Plotnykov, E., Hlazova, H. (2010). Rastytelnye antyoksydanty v proyzvodstve myasnykh izdelyi. Myasnaya industriya, 7, 26-28.

[15] Hurynovych, H., Lysyn, K., Potypaeva, N. (2005). Preparat dlya prodleniya sroka hodnosty miasnikh polufabrykatov. Myasnaya industriya, 2, 31-33.

[16] Hurynovych, H., Potypaeva, N. (2009). Naturalnyi antyokyslytel dlya myasnykh produktov. World meat technologies, 2-3, 36-39.

[17] Pasichniy, V., Khomenko, Y., Polumbryk, M. (2014). Using of polymers as carriers in encapsulation of spice oleoresins. Ukrainian Journal of Food Science, 2 (2), 213-219.

[18] Litvinova, I., Savinok, I. (2014). Study the influence of complex additive «maltovin» on the functional properties of frozen meat semi finished products. ScienceRise, 5 (2 (5)), 54-59. doi: 10.15587/23138416.2014.31981

[19] Litvinova, I. (2013). Doslidzhennya vplyvu kompleksnoi dobavky «Maltovyn» na funktsionalni vlastyvosti myasnykh modelnykh system. Kharchova nauka i tekhnolohiya, 23, 39-42.

[20] Dehtiarev, P., Pykunov, A., Sverhunenko, S. (2004). Novie dannie ob antyoksydantnoi aktyvnosti shlemnyka baikalskoho. Myasnaya industriya, 5, 51-52.

[21] Bazarnova, Yu., Kolodiaznaia, V., Dmytryeva, Y. (2003). Issledovanie antyoksidantnoi aktivnosti pryrodnikh veshchestv. Khranenie i pererabotka selkhozsirya, 10, 66-71.

[22] Ricardo da Silva, J. M., Rigaud, J., Cheynier, V., Cheminat, A., Moutounet, M. (1991). Procyanidin dimers and trimers from grape seeds. Phytochemistry, 30 (4), 1259-1264. doi: 10.1016/s00319422(00)95213-0

[23] Kandaswami, C., Middleton, E. (1994). Free Radical Scavenging and Antioxidant Activity of Plant Flavonoids. Advances in Experimental Medicine and Biology, 366, 351-376. doi: 10.1007/978-1-46151833-4_25

[24] Sharigyna, Ya., Baydalynova, L. (2012). Sravnytelnaya effektyvnost rastytelnikh antyoksydantov na osnove ekstrakta rozmaryna pry proizvodstve myasnikh zamorozhennikh izdeliy. Izvestiya KGTU, $18,111-117$.

[25] Bozhko, N., Tishhenko, V., Pasichniy, V. (2017). Ekstrakt zhuravlini v texnologii varenih kovbas z myasom vodoplavnoyi ptyci. Naukoviy visnyk LNUVMBT imeni S. Z. Gzhyczkogo, 19 (75), 106-109.

[26] Antipova, L., Glotova, I., Rogov, I. (2001). Metody issledovaniya myasa i myasnyh produktov. Moscow: Kolos, 576.

[27] GOST R 55810-2013 (2014). Myaso i myasnie produkti. Metod opredeleniia tiobarbiturovogo chisla. Moscow: Standartinform, 21. 